\title{
NOS VAGÕES DA HISTÓRIA: A MEMÓRIA DOS PARNAIBANOS SOBRE A ESCOLA DOS FERROVIÁRIOS NO PIAUÍ (DÉCADAS DE 1950 A 1980)
}

\author{
Cláudia Cristina da Silva Fontineles ${ }^{1}$ \\ Maria Dalva Fontenele Cerqueira ${ }^{2}$
}

\begin{abstract}
Resumo
A implantação do sistema ferroviário em Parnaíba gerou euforia entre os parnaibanos, que conviveram por mais de sessenta anos com os trens e com os benefícios sociais que ele gerou na região, entre os quais, destaca-se a escola que atendia a família dos ferroviários. Esta escola foi ignorada por muito tempo pelas narrativas históricas. O presente texto visa dar notoriedade para a relevância desta escola para os ferroviários e para a história da educação no cenário parnaibano e piauiense. A pesquisa trabalhou com fontes históricas escritas - documentais e hemerográficas - e com relatos orais dos sujeitos históricos envolvidos com a configuração histórica em apreço por meio da metodologia da História Oral, visando acionar as memórias dos ferroviários e de seus familiares sobre esta escola. Isso possibilitou entender sobre a criação deste estabelecimento escolar e sua inserção na sociedade parnaibana, o status da escola, o prestígio social usufruído por seus funcionários e estudantes, bem como a formação do quadro docente e, assim, entender um pouco sobre a história da educação do período. Para tanto, manteve interlocução teórica com as pesquisas de Walter Benjamin, Michel de Certeau, Pierre Nora e Francisco Hardman.
\end{abstract}

Palavras chave: História. Educação. Memória. Ferroviários. Parnaíba (PI).

\section{IN THE WAGONS OF HISTORY: the memories of "parnaibanos" about the railway workers school in Piauí (1950's to 1980's)}

\begin{abstract}
The implementation of the railroad system in the city of Parnaíba provoked euphoria among its citizens, known as "parnaibanos", who have lived for more than sixty years with the trains and the social benefits they have generated in the region, among them, the creation of a school to be attended by the railroad family. This school has been ignored for too long by historical narratives, for this reason this paper aims to highlight the importance of this school to the railroad system and to the history of education in the city of Parnaíba and in the state of Piauí. The research was based on written historical sources - documentary and newspapers - and on oral reports produced by the individuals who were part of this historical context using the methodology of Oral History in order to trigger the railway workers and their families' memories about this school. The investigation outlines the creation of the school and its insertion in the city society, the status of the school, the social prestige enjoyed by its officials and students, as well as the formation of the teaching staff which allowed the understanding about the history of this period of education. The theoretical dialogue is grounded on Walter Benjamin, Michel de Certeau, Pierre Nora and Francisco Hardman's studies.
\end{abstract}

Keywords: History. Education. Memory. Railway Workers. Parnaíba (PI).

\section{Introdução}

Essa máquina incrível que já significou o fio condutor das mudanças revolucionárias é passada, agora, para trás. É expulsa do terreno da história. Dinossauro resfolegante e inclassificável, a locomotiva está condenada a vagar incontinente pelos campos e redutos aflitos da solidão.

(HARDMAN, 2005, p. 51-52)

\footnotetext{
${ }^{1}$ Doutora em História pela Universidade Federal de Pernambuco. Professora adjunta da Universidade Federal do Piauí e coordenadora de História PIBID/UFPI/CAPES da Universidade Federal do Piauí, atuando na Pós-graduação em História do Brasil e no Departamento de Métodos e Técnicas de Ensino. E-mail: cfontinelles@yahoo.com.br

${ }^{2}$ Mestre em História do Brasil pela Universidade Federal do Piauí. Licenciada em História pela Universidade Estadual do Piauí. Especialista em História do Brasil pela Universidade Federal do Piauí. Professora da Secretaria de Estado da Educação - Seduc (PI). E-mail: dalvaclio@gmail.com
} 
A avassaladora máquina a que se refere Francisco Hardman - o trem - também foi superada no Piauí. Sua implantação inspirou euforia entre os parnaibanos, que conviveram por mais de sessenta anos com os trens e com seus muitos frutos, entre os quais destacam-se o Clube dos Ferroviários e a escola. Esta por muito tempo ficou ignorada pelas narrativas históricas, pelo simples silêncio historiográfico acerca de sua importância para a sociedade parnaibana e, consequentemente, para a história da educação do nosso estado.

O presente texto visa dar notoriedade à relevância desta escola para a história dos ferroviários e para a história da educação no cenário parnaibano e, dessa forma, reativar as discussões acerca da história das ferrovias em terras piauienses e os desmembramentos disso em diferentes esferas de nossa história, mais especificamente no campo da instrução. Para tanto, foi necessário acionar as memórias dos ferroviários e seus familiares sobre esta escola por meio da metodologia da História Oral. Isso possibilitou entender a importância dessa escola na vida dos ferroviários e de seus familiares, procurando discutir o lugar social desta escola no cenário parnaibano, o prestígio social usufruído por seus funcionários e estudantes, o cotidiano dessa comunidade escolar e, assim, refletir sobre a história da educação do período e sua relevância para o entendimento da história da cidade de Parnaíba e do estado do Piauí.

Nesse sentido, trabalhamos como as fontes consultadas denominavam os discentes desta escola como "crianças ferroviárias", discutindo em que medida estendiam aos estudantes desta escola os adjetivos do ofício profissional dos pais, e consigo, punham em evidência o prestígio social usufruído por estes trabalhadores no período. Tudo isso sofreu um forte abalo com a desativação das ferrovias e da própria escola, embora em ambos os casos, este prestígio tenha conquistado o território da memória dos ferroviários e de seus familiares e como tal tenha se inscrito na história do Piauí, estabelecendo o diálogo entre o presente e o passado que é "ativado" pela narrativa aqui construída.

\section{Ferroviários Piauienses: nas trilhas da memória}

Recebidas como símbolo do progresso e da modernidade, as estradas de ferro chegaram ao Brasil no século XIX, mudando a paisagem local e o cotidiano muitos brasileiros, dado que a maioria desconhecia totalmente este novo meio de transporte. No entanto, o estado do Piauí, teve realizado o desejo de ver o trem cortando seu território apenas no século $\mathrm{XX}$, a falta de recursos financeiros foi uma das justificativas apontadas pelo poder público para justificar a demora na construção da ferrovia piauiense. 
Os caminhos de ferro só chegaram ao Piauí no início do século XX, quando os primeiros trilhos foram assentados pela South American Railway Company Ltda, empreiteira responsável pela construção da Rede de Viação Cearense.

A estrada de ferro Amarração-Campo Maior, construída com recursos federais, teve sua construção iniciada na cidade de Parnaíba, que também se tornou a cidade sede da ferrovia piauiense, mas a quebra do contrato com a empreiteira fez com que os serviços fossem paralisados e retomados apenas em 1916, quando a seca fez com que um grande número de imigrantes adentrasse ao território piauiense em busca de trabalho, a maioria advindos do vizinho estado do Ceará.

Diante da grande massa de imigrantes que chegavam ao Piauí, principalmente à cidade de Parnaíba, na época o maior centro comercial do estado, o Governo Federal, atendendo ao pedido dos representantes do estado, autorizou a construção de uma estrada de ferro, ligando o litoral à capital, Teresina, a Estrada de Ferro Central do Piauí.

O primeiro trecho foi concluído na década de 1920, ligando Parnaíba à cidade de Piracuruca, e assim permaneceu até a década de 1930, quando a construção foi retomada. A chegada do trem alterou de forma significativa o cotidiano dos piauienses do norte do estado, que passaram a conviver com a "Maria Fumaça" e todas as mudanças que sua chegada provocou.

Parnaíba foi cidade sede da ferrovia, abrigou posto de saúde, escritório, oficinas, armazém, guaritas e duas estações ferroviárias e um grande número de operários. Além das obras construídas para o funcionamento do trem também foram construídos um clube para a "família ferroviária" e uma escola destinada aos filhos dos ferroviários. A ferrovia teve seu período áureo entre as décadas de 1930 a 1950, e enfrentou, na segunda metade do século XX, um longo processo de desmonte, o que culminou com a desativação na década de 1980. No decorrer desse processo, as mudanças foram vividas por seus funcionários que, em cada nova administração, viam aumentar a ameaça do desemprego. O trem - que um dia foi festejado e desejado - virou resíduo para a memória; perdeu a corrida para o automóvel; restaram apenas fragmentos de trilhos e de dormentes, prédios abandonados, estações desativadas e muita saudade nos ferroviários, hoje aposentados, que contam suas memórias e, por meio delas, nos permitem conhecer um pouco do cotidiano vivido.

Entre as reminiscências do trem em Parnaíba destacam-se: a linha férrea que cortava a cidade em direção a Teresina - ainda visível entre as pedras do calçamento; os vários prédios que outrora integraram o cotidiano dos ferroviários como local de trabalho, escola, tratamento de saúde, espaço de sociabilidades compõem o acervo arquitetônico da cidade e resistem à ação do tempo. A estação de passageiros que, segundo Renato Castelo Branco, era um lugar onde "madrugavam os cegos, os bagageiros e os moleques com tabuleiros de cocadas e rebuçados aguardando a chegada do trem de 
Amarração, ou de Piracuruca ou de Piripiri” (BRANCO, 1981, p. 21), abriga o Museu do Trem do Piauí, um "espaço de recordação" dos parnaibanos.

Essa história deixou marcas tão agudas na cidade litorânea que seus registros se alastraram muito mais que apenas à dimensão física; sua presença é realçada e sentida nas manifestações parnaibanas e em tudo que se refere a este município, inscrevendo-se a todo instante na cartografia dos sentimentos que compõem sua população (REZENDE, 26.jul.2012). Os prédios que formaram o complexo ferroviário, estão postos para os habitantes como um "fundamento normativo" do "tempo do trem", pois visam despertar recordações das idas e vindas dos trens de cargas e passageiros e a movimentação no local, e passam a funcionar como "lugares de memória" daquilo que já não mais é, mas ainda o é enquanto memória de um grupo, entendidos como "a justaposição de duas ordens de realidades: uma realidade tangível e apreensível, às vezes material, às vezes menos, inscrita no espaço, no tempo, na linguagem, na tradição; e uma realidade puramente simbólica, portadora de uma história” (NORA, 1997, p. 226).

Sob essa perspectiva, o local inscreve suas marcas em seus habitantes, mas também deles recebe seus sentidos e significados,

[...] os significados dos locais das gerações surgem do vínculo duradouro que famílias ou grupos mantêm com um local determinado. Assim surge uma relação estreita entre as pessoas e o local geográfico: este determina as formas de vida e as experiências das pessoas, tal como estas impregnam o local com sua tradição e histórias (ASSMANN, 2011, p. 328).

Da construção da Estrada de Ferro Central do Piauí até sua desativação passaram-se mais de sessenta anos de convivência dos parnaibanos com os "locais honoríficos" escolhidos para abrigar o trem e garantir seu funcionamento. Para que as viagens fossem seguras e o percurso realizado com sucesso foi preciso um grande número de homens, os ferroviários, e de algumas mulheres que, juntos, trabalhavam nos escritórios, na escola, no posto médico, nas estações, nos armazéns e nos trechos ao longo da linha.

Era um trabalho duro e cansativo, mas que os ferroviários realizavam com destreza e maestria; atuavam como músicos de uma orquestra, se um desafinasse colocava em risco não apenas o trabalho, mas a vida daqueles que usavam o trem para visitar os parentes, fazer negócios, para o lazer e o divertimento na praia de Luís Correia. Nesse sentido, Goethe Pires de Lima Rebelo, ao narrar sobre o que ele chamou de Tempos que não voltam mais, permite visualizar um pouco desse frenesi cotidiano provocado pelo trem que, segundo ele, "vinha desde o terminal de Piracuruca, apanhava sua lotação total nas estações intermediárias de Frecheiras, Bom Princípio, Cocal e etc., para onde convergiam as inúmeras pessoas que moravam perto dessas estações, em 
sítios e roçados, e que, juntos demandavam à Parnaíba" em busca de diversão nas festas natalinas e para a tradicional Missa do Galo (REBELO, s/d, p. 81).

A construção da Estrada de Ferro Central do Piauí, em Parnaíba, marcou de maneira indelével a história desta cidade, a ponto de ser considerada um dos "desejos mais ardentes" de seus habitantes, desde o lançamento da pedra inaugural de sua implantação, como noticiado pelo jornal $A$ semana, em matéria intitulada "Estrada de Ferro - Festa Cívica"3.

O dia 19 amanhecera nublado, mas cheio dessa claridade agradável do sol tépido de inverno, um chuvisco fino, tenuíssimo, cahia a intervalhos. Grande era o movimento na cidade, sobretudo na Rua Grande e suas imediações.

Parnahyba desde cedo apresentava um ar vivo, acentuado, de festa. Música, ornamentação, flores, fortes tons de alegria em todas as ruas; riso franco e espontâneo aflorando em todas as bocas. É que naquele diz o povo ia ver a quase realização de seus desejos mais ardentes; ia ser lançada a pedra fundamental da nossa estação de caminho de ferro e uma locomotiva, a primeira do Piauhy, ia correr no trecho único até hoje construído neste Estado. [...] Quando alli chegamos já era intenso o movimento do povo, que se acotovelava impaciente e sôfrego. Junto a machinha e a cavidade aberta para receber a pedra da gare achava-se na meza, em torno da qual tomaram assento o dr. Miguel Bacellar, engenheiro-chefe da Construção, o dr. X. Pacheco, engenheiro da mesma, vários empregados da Estrada e os membros do Directório Civico. [...] Ás 10 horas, pouco mais ou menos, fez uso da palavra o dr. Miguel Bacellar, que, com muita facilidade e belleza de estylo, pronunciou uma oração alusiva ao acto e que impressionou agradavelmente a todos que a ouviam. Foi lavrada uma acta, que foi assignada por grande número de pessoas alli presentes (A SEMANA, 1916, p. 01- grifos nossos).

O entusiasmo com o lançamento da pedra fundamental para a construção da Central do Piauí era evidente e contagiou a cobertura jornalística. A cidade festejante foi enfeitada com flores para a ocasião que se tornou ato solene. Segundo o jornal, o dia 19 de novembro de 1916 foi um dia festivo. As comemorações que começaram de manhã perduraram durante todo o dia e findaram à noite com um baile realizado nos salões da Booth Line, para os engenheiros, e um sarau popular no Largo da Matriz, onde "o local estava caprichosamente preparado, com seu coreto interessante, com sua música improvisada e barulhenta e as divisões do terreno para os vários gêneros de dança usados pelo povo" (A SEMANA, 26 nov. 1916, p. 01). O pioneirismo em relação a todo o Estado era saudado como mais um feito e lustrava ainda mais o brilho de tal conquista realizada por Parnaíba.

A tão comemorada estação ferroviária de Parnaíba foi inaugurada em 1920 e as demais estações construídas até Piracuruca estenderam até o ano de 1923. Em Parnaíba, foram construídas nesse intervalo de tempo duas estações ferroviárias, sendo uma no centro da cidade, a estação central, que recebia os trens vindos das outras estações e onde se decidia para onde o trem seguiria e

\footnotetext{
${ }^{3}$ Optamos por transcrever a notícia respeitando a forma ortográfica em que se encontra no jornal consultado.
} 
outra, no povoado Catanduvas, a estação Floriópolis. Além das estações, também foram construídos currais, armazéns, pátios, a oficina, posto médico, escola, clube dos ferroviários, guaritas entre outros edifícios que serviram para a ferrovia e seus ferroviários.

$\mathrm{Na}$ década de 1950 foram construídos outros edifícios, dentre os quais destacam-se a Vila Operária Major Santa Cruz, um conjunto de casas para os trabalhadores de turmas de conservação dos trilhos e dormentes e para os mestres de linha que vinham transferidos de outras cidades piauienses ou mesmo os oriundos de Parnaíba que não dispusessem de moradia.

Em meio a ameaças e promessas, a ferrovia foi desativada na década de 1980. As peças da oficina e outros objetos foram levados para São Luís, capital do Maranhão. Depois que a Central do Piauí passou à condição de Distrito de Operações do Piauí subordinado, em 1964, à Rede de Viação Cearense, em 1968, foi ligada à Estrada de Ferro São Luís - Teresina. Os ferroviários piauienses guardam na memória os (res)sentimentos do desmonte da ferrovia piauiense. $\mathrm{O}$ medo, a insegurança, assim como a saudade são sentimentos realçados nas memórias daqueles que fizeram parte da história da ferrovia em Parnaíba.

Na condição de narradores, esses ferroviários compartilharam com o presente suas maneiras de ver, sentir e contar a história desse tempo; à sua maneira, permitiram que o presente se mantivesse conectado com esta dimensão do passado; contaram suas experiências; compartilharam seus saberes naquilo que Walter Benjamin denominou de "arte de narrar" e na sabedoria que ela comporta, pois, segundo ele,

Ela tem sempre em si, às vezes de forma latente, uma dimensão utilitária. Esta utilidade pode se constituir seja num ensinamento moral, seja numa sugestão prática, seja num provérbio ou numa norma de vida - de qualquer maneira $o$ narrador, o narrador é um homem que sabe dar conselhos [...] O conselho tecido na substância viva da existência tem um nome: sabedoria (BENJAMIN, 1994, p. 04).

No tocante à discussão sobre a narrativa, Benjamin afirma que a "memória é a mais épica de todas as faculdades. [...] A reminiscência funda a cadeia da tradição. Ela corresponde à musa épica no sentido mais amplo. Entre elas encontra-se em primeiro lugar a encarnada pelo narrador. Ela tece a rede que em última instância todas as histórias constituem entre si”. O narrador tem um lugar privilegiado por ser o detentor da sabedoria que é contada aos outros do grupo. Assim, a memória cumpre um papel central de destaque dentro da história, surgindo como "musa da narrativa".

A memória aqui é entendida segundo a proposição formulada por Michael Pollak, na qual os acontecimentos, personagens e lugares são os elementos constituintes da memória coletiva de um grupo. Para o autor, a memória é um fenômeno construído coletivamente e que, mesmo submetido a flutuações, existem "marcos” invariáveis e imutáveis que envolvem o grupo. 
Entendemos que a memória também é parcial e seletiva, uma vez que nem todas as experiências vivenciadas pelos sujeitos históricos são (re)criadas ou (re)lembradas. O que temos do passado são apenas vestígios, portanto, resíduos da memória que possibilitaram os ferroviários piauienses reelaborar o passado representado pelas concepções acerca do que foi vivido pelo grupo de ferroviários no cotidiano da ferrovia.

Essa memória ou memórias responde a um chamado do tempo presente, por tanto, é do tempo presente que os ferroviários são convidados por meio de entrevistas - mediadas pela metodologia da história oral - a se recordam dos acontecimentos vividos no passado, daí o entendimento de que precisamos ter da fluidez da memória, dos fragmentos das lembranças que restam de um passado distante ou, como propõe Verena Alberti (2014, p. 15) “[...] pedaços do passado, encadeados em um sentido no momento em que são contados e em que perguntamos a respeito.".

Endossando este entendimento, a historiadora Cláudia Fontineles (2009, p. 71) esclarece que “a memória dos homens é fragmentada, não sendo capaz de traduzir nenhuma totalidade, apenas suas reminiscências, seus resíduos. Suas apropriações são fracionadas e relidas conforme as possibilidades do presente que a evoca, daí promovendo seus encantos e seus desafios". Nesse sentido, a memória aqui não será entendida como "espelho" do passado e sim como uma construção sobre o passado em função do presente. Entendemos também que a memória não armazena tudo o que vivemos, as nossas experiências, mas existem aqueles acontecimentos que ficam guardados, escondidos no sótão da memória, como "recordações latentes".

No entanto, para Assmann Aleida (2011, p, 274) “[...] como as coisas velhas, também as recordações latentes existem em um estado intermediário, de ondem incidem na escuridão do pleno esquecimento.". A autora defende a existência dos "estabilizadores da recordação" e apresenta a língua como um dos mais poderosos estabilizadores das recordações, uma vez que, pela língua as recordações são socializadas pelo grupo. Além disso, identifica o afeto, os símbolos e os traumas, como estabilizadores de recordações e subjetividades.

\section{Núcleo Elzir Cabral: a relevância para a história da educação piauiense}

A escola dos ferroviários recebeu diferentes denominações durante o período de seu funcionamento em Parnaíba, mas foi como Elzir Cabral que ficou conhecida e registrada na memória dos parnaibanos aqui entrevistados. Sua existência marcou de tal forma a memória dos ferroviários, dos estudantes e das professoras, que estas últimas também reivindicam o direito de serem lembradas como mulheres ferroviárias, que teriam feito parte tanto da história da ferrovia quanto da história da educação parnaibana. 
Em comparação ao número de homens, era pequeno o número de mulheres que trabalhavam na ferrovia. Mas, elas tiveram uma atuação expressiva neste cenário, ajudando na limpeza, nos escritórios, na estação, no clube dos ferroviários, nas festas e na escola. No geral, elas começavam a trabalhar por intermédio de um parente, fosse ele o marido, o pai ou irmão, que já fazia parte da empresa. O Almanaque da Parnaíba (1944, p. 337) apresenta o quadro de funcionários da sede administrativa da ferrovia e, entre eles, destaca as senhoras: Eneida da Silva Campos (Secretária), Jacy da Silva Campos e Risoleta Ribeiro da Silva (Serviço do Pessoal), Darcília de Freitas Mendes (auxiliar do Almoxarifado), Alith da Silveira Ribeiro (auxiliar de Contabilidade).

A presença feminina é realçada pelas mulheres entrevistadas nesta pesquisa. Essas mulheres orgulham-se de ter integrado aquilo que elas, assim como os homens, chamam de "família ferroviária". Nas entrevistas consideramos as orientações de Michel de Certeau acerca da maneira como as pessoas se recordam do passado:

[...] o modo de rememoração é conforme o modo da inscrição. Talvez a memória seja aliás apenas essa "rememoração" ou chamamento pelo outro, cuja impressão se traçaria como em sobrecarga sobre um corpo há muito tempo aletrado jamais sem o saber. Essa escritura originária e secreta "sairia" aos poucos, onde fosse atingida pelos toques. Seja como for, a memória é tocada pelas circunstancias, como o piano que "produz" sons ao toque das mãos. Ela é sentido do outro (CERTEAU, 2003, p. 163).

Assim, as circunstâncias de que fala Certeau são geradas no momento da entrevista em que despertamos suas lembranças. Por meio das "rememorações" das ferroviárias interpretamos os sentidos por elas atribuídos à existência da escola e às suas experiências no trabalho. A memória, portanto, é feita de lembranças que são compostas de pequenos fragmentos. As lembranças precisam ser tocadas para despertarem. Quando lembramos, não estamos revivendo o passado. Este já passou. O que aflora são pequenos fragmentos vividos, como disse Certeau (2003, p. 162) “de um corpo, um brilho no olhar". Para o autor, “A memória não possui uma organização já pronta de antemão que ela apenas encaixaria ali. Ela se mobiliza ao que acontece - uma surpresa, que ela está habilitada a transformar em ocasião. Ela só se instala num encontro fortuito, no outro".

Dessa forma, não podemos esperar dos colaboradores(as) um relato cronológico das suas lembranças. As diferentes experiências vividas pela comunidade afetiva ou de destino estão guardadas na memória que precisam de "uma surpresa" para emergirem durante a entrevista, pois como defende o pensador francês "a memória vem de alhures, ela não está em si mesma e sim noutro lugar, e ela desloca [...]" (CERTEAU, 2003, p. 163-164).

São muitas as memórias sobre a ferrovia e sobre sua relação com a cidade de Parnaíba. A ferrovia possibilitou a instalação de uma rede de infraestrutura que influenciou os mecanismos de 
sociabilidade entre os ferroviários. Uma das construções foi o Posto Médico, construído na década de 1940, tinha médicos e enfermeiras que atendiam os ferroviários e seus familiares quando estavam doentes. Outro elemento era a Cooperativa, na qual os ferroviários podiam fazer suas compras e pagar quando recebiam seus rendimentos, pois lá "tinha de tudo", desde a alimentação até o vestuário, conforme declaração dos ferroviários.

O Clube, com sede na Avenida São Sebastião, construída também na década de 1940, unia os ferroviários em torno de uma "paixão nacional": o futebol. O "Ferrim", apelido carinhoso pelo qual ficou conhecido o Ferroviário Atlético Clube, time dos ferroviários em Parnaíba, tinha adesão de todos os ferroviários, inclusive da empresa que financiava e dispensava os funcionários no final do expediente ou contratava jogadores da cidade para fazer parte do time dos ferroviários.

Todo esse patrimônio servia aos seus funcionários que tinham seus momentos de lazer como festas, jogos. Os filhos e as esposas também eram beneficiados com a existência da escola criada e mantida pela Estrada de Ferro. A respeito desta escola, são poucas as fontes encontradas sobre sua existência em Parnaíba. As pesquisas realizadas sobre a ferrovia mencionam sua existência, mas não pontuam informações específicas. Existe um ocaso que a envolve e dificulta o estudo a seu respeito, o que nos remete ao que adverte Carlo Ginzburg (1989, p. 149) sobre a importância de se "examinar os pormenores mais negligenciáveis [...]", os "indícios imperceptíveis para a maioria". Mesmo as fontes orais - assim como as escritas - são poucas, muitas professoras já faleceram ou tem uma idade avançada, o que gera a perda progressiva do acesso aos relatos orais.

O Almanaque do Cariri, na edição de 1952, em texto que trata da Estrada de Ferro Central do Piauí durante a administração do engenheiro parnaibano Alberto Tavares Silva, ao destacar a atuação do referido político ${ }^{4}$ na criação da escola e nas demais medidas tomadas para o funcionamento da ferrovia, permite entender muito sobre seu funcionamento:

Foi criada pelo Engenheiro Alberto Silva e inaugurada a 15 de novembro próximo findo, sob os melhores auspícios, a "Escola Darcy Vargas", estabelecimento de elevado alcance dedicado aos filhos dos ferroviários, benemérita instituição que já acolhe mais de 200 crianças ferroviárias de ambos os sexos e lhes ministra a instrução no sentido mais amplo da palavra.

Tem como Diretora a inteligente senhorita Helena Ramos Vieira, cujo esforço e dedicação, muito tem concorrido para o completo êxito que vem obtendo aquela Instituição, em todos os setores educacionais possíveis de serem mantidos ali: Cortes e Costuras, Trabalhos manuais, Bordados à máquina, Instrução religiosa, e Educação Física, além dos cursos de letras e números.

\footnotetext{
${ }^{4}$ Denominamos Alberto Silva de político porque neste período, 1952, embora ele estivesse à frente da Estrada de Ferro Central do Piauí, já era forte liderança política em Parnaíba, tendo inclusive assumido o comando do Executivo Municipal, no ano de 1948, e o cargo de deputado estadual, em 1950, pela UDN, cargo do qual se afastou para comandar os caminhos ferroviários no Piauí (FONTINELES, 2009).
} 
Adida à Escola Darcy Vargas, funciona, ainda o Curso de Escoterismo, confiado a um competente Instrutor Militar.

Digno de nota, também, é o concurso que a Diretora da Escola Darcy Vargas, recebe por parte de suas colegas, uma plêiade de jovens professores, competentes e verdadeiramente dedicadas à causa que abraçam (ALMANAQUE DO CARIRI, 1952, p. 753-754 - grifos nossos).

O prestígio social usufruído por essa instituição educacional é notório, bem como a interferência das influências políticas do período: o nome da escola ser uma homenagem à esposa do então presidente da República - Getúlio Vargas; o caráter cívico, moral e técnico assumido por algumas disciplinas - evidenciados em cursos como o de Escoterismo -, bem como a influência de setores confessionais e militares no seio escolar, pois eram considerados "elementos essenciais da moralidade: o espírito de disciplina, a dedicação aos ideais e a consciência da responsabilidade" (SILVA apud RIBEIRO, 2007, p. 148).

Porém, o que mais impressiona é como o Almanaque denomina os discentes desta escola: crianças ferroviárias, como se a função profissional dos pais fosse extensiva às crianças. Essa denominação, mais que atribuir um caráter pejorativo aos educandos, parecia querer estender o prestígio usufruído por seus familiares, haja vista o reconhecimento social obtido por este grupo profissional.

Outra notícia sobre a referida escola foi encontrada no jornal teresinense $O$ Piauí, também de 1952, segundo a qual:

A Escola de Cooperação Educacional à família do Operariado está funcionando e produzindo os melhores frutos. Sessenta e cinco alunos do sexo masculino ali recebem instrução; criou-se um Corpo de Escoteiros para melhor prender atenção dos meninos e foi doada a respectiva farda, completa. Conseguiu, destarte, a direção da Estrada, aliar o ensino didático ao esporte e à educação física. Cento e trinta alunas, aproximadamente, estão matriculadas nos cursos femininos da Escola, onde recebem ao mesmo tempo que a instrução propriamente dita, lições de corte, costura, bordados, trabalhos manuais diversos. $\mathrm{O}$ ensino dessas especialidades foi confiado a professoras diplomadas em alta costura, e podemos admitir como magníficos os resultados obtidos (O PIAUÍ, 1952, p. 02).

Em mais esta fonte é possível observar o caráter moral e tecnicista da escola - articulado à presença de princípios militares -, bem como sua preocupação com a educação para o esporte e para a prática de atividades físicas pelos estudantes, como caráter preventivo de promoção da saúde física e social, elemento muito prestigiado pelo projeto nacionalista dos governos Vargas, inclusive durante seu período democrático.

De acordo com as fontes consultadas, a escola para os filhos e filhas dos ferroviários piauienses começou a funcionar em Parnaíba na década de 1950, com o nome da esposa do então presidente da República, o que certamente atrairia a simpatia do comandante político do país e, 
mais, utilizaria a escola como uma forma de tornar perene a homenageada e todos os fragmentos da história a que esta estavam relacionados.

A sede da escola, segundo as rememorações da professora Maria Helena Brandão, que começou a trabalhar na escola em 1950, a convite de Alberto Silva, era onde hoje é a Escola Municipal Roland Jacob.

Ainda na década de 1950, a escola passou a se chamar Escola Técnica de Educação Familiar, tendo, em 1963, como diretora a professora Jusuila Marinho Gonçalves. Já em 1966 passou a se chamar Centro de Ensino Primário dos Ferroviários do Piauí, sob a direção da mesma professora. Nesse período, a ferrovia piauiense deixara de ser Central do Piauí e passou a ser Distrito de Operações do Piauí - DOPI, sob a tutela da Rede de Viação Cearense. Isso já indicava o avanço do caminho da desativação da empresa.

A revista Contemporânea, de 1960, publicou uma matéria sobre a solenidade realizada em Parnaíba, quando o engenheiro Petrarca Rocha Sá completava um ano administrando a Central do Piauí. Os discursos proferidos apresentando as realizações do engenheiro, também foram publicados. Na ocasião foram apresentadas realizações que informavam visar à segurança no setor de transportes e à criação de novos departamentos. O setor da Educação, também foi contemplado, onde foi citado que:

O engenheiro Petrarca Sá, com decidida colaboração da professora Jesuila Gonçalves Marinho, pode elevar a matricula da Escola Técnica de Educação Familiar, mantida pela Central do Piauí para os filhos dos Ferroviários, de 280 alunos para 551, numa medida de quase 100\% (COMTEMPORANEA, 1960, p. 29).

Na década de 1970, já se tratava do Distrito de Transporte do Piauí, ligado à Estrada de Ferro São Luís - Teresina e a Escola Engenheiro Valdivino Leão de Carvalho do Núcleo Social Ferroviário Elzir Cabral. Valdivino Leão de Carvalho foi nomeado chefe do Distrito de Operações do Piauí - DOPI pela Portaria n. 113/SUP, cargo que ocupou de 05 de agosto de 1964 a 14 de abril de 1967, quando foi substituído por Manoel Alves da Silva. Nesse período a escola teve como diretora a professora Luzia Campos Silveira, mas foi como Escola Elzir Cabral que ficou conhecida e está na memória dos parnaibanos no presente. O engenheiro Elzir de Alencar Araripe Cabral foi Superintendente da Rede de Viação Cearense em 1968.

Nesse percurso, a incorporação da Central do Piauí pela Rede Ferroviária Federal, na década de 1950, provocou mudanças também na escola para os filhos dos ferroviários. A Central do Piauí perdeu a condição de ferrovia e passou primeiro à condição de Distrito de Operações - DOPI subordinado à Rede de Viação Cearense e depois Distrito de Transportes do Piauí, ligado à Estrada 
de Ferro São Luís - Teresina. A escola também mudou de nome e de local de funcionamento, indicando uma constante disputa pela história e pela memória que se pretendia perenizar.

Na década de 1950 a escola funcionava em prédio perto da estação, próximo do atual Corpo de Bombeiros. Na década de 1960 funcionou na Rua Grande, Avenida Presidente Vargas, onde atualmente é o prédio do Banco do Bradesco e depois mudou-se para perto da estação novamente, onde atualmente funciona o prédio da Escola Municipal Senador Alberto Silva, em uma forte imbricação entre este engenheiro e a escola na qual outrora tivera forte influência na nomeação de funcionários, assim com já fizera com a própria empresa ferroviária. Nesse local, a escola funcionou até sua extinção.

Os vários lugares e nomes recebidos por esta instituição escolar permitem denotar os diferentes interesses que colidiam entre si e disputavam o status de ser eternizados em um prédio público - como virou uma prática comum no cenário político e administrativo brasileiro.

Com a extinção da escola, as professoras que não tinham idade e tempo de serviço para serem aposentadas, foram encaminhadas para trabalhar no escritório do Distrito de Operações. Uma das professoras que atuaram nesta escola foi a professora aposentada Evangelina Maria Silva e Souza, que se recorda dos anos que passou trabalhando na escola Valdivino Leão de Carvalho e lamenta pelo fim da escola e da ferrovia. Ao narrar suas lembranças, recorda da infância e de sua escola em Parnaíba:

Eu comecei a trabalhar em 1964, eu fui nomeada para ser professora de Artes na escola. O Diretor da Estrada era Solheiros. Eu estudava na Escola Doméstica de Natal e tinha chegado aqui. Eu estudei em Parnaíba e quando terminei o Ginásio eu fui para Natal, lá estudei na Escola Doméstica. Eu fiz o Ginásio no Ginásio São Luís Gonzaga quando ficou misto. Alberto Silva trouxe dois diretores de Fortaleza e o Ginásio abriu as portas para garotos e garotas. Eu entrei na Estrada muito nova, com dezenove anos. Eram apenas mulheres. E só recebia filhos de ferroviários. Era o Primário, e tinha Arte, corte e costura, bordado a máquina.

Evangelina, que foi contratada para ser professora de Artes, formada pela Escola Doméstica de Natal, entrou para a Escola em 1964 e se recorda que, além de oferecer o Ensino Primário, que corresponde hoje ao Ensino Fundamental, também ensinava Corte Costura, Bordado, Crochê à Máquina e a produzir Flores, entre outras coisas. Pelos relatos de Evangelina, podemos identificar que, na década de 1960, a escola mantinha os cursos que eram ofertados na década de 1950.

A entrevistada afirma que "A escola tinha uma boa estrutura e oferecia um bom ensino. A direção era com funcionárias da Rede. Esse foi meu primeiro e único emprego". Quando questionada sobre o motivo da extinção da escola, a entrevistada relaciona o fim da escola ao fechamento da ferrovia: 
Foi a Estrada de Ferro que foi fechando, não foi a escola, foi a própria Estrada de Ferro. Ela foi fechando devagar, primeiro foi a escola, o posto médico foi o último. Depois nós ficamos dando expediente na escola e esperando as decisões. Depois que eles decidiram fechar, a maioria das professoras saíram e outras foram para o escritório. Eu fui para o escritório. No escritório eu era Agente Administrativo, eu cuidava de fazer folha de pagamento, aposentadoria. Lá tinham mulheres e homens. A convivência era muito boa, eram quatro mulheres, eu, a Mariazinha, Dulcineide e uns seis homens no escritório. Era bom porque os homens eram ótimos, maravilhosos. Eles contavam muitas histórias da Estrada de Ferro. Eles cotavam muitas histórias porque quando eu cheguei no escritório a estrada já se resumia ao escritório. Eles vinham da famosa Estrada de Ferro Central do Piauí, que foi a primeira empresa de Parnaíba, que era o sustentáculo econômico de Parnaíba. Ser ferroviário naquela época era tudo. O salário do ferroviário era lá em cima, querida. A Estrada de Ferro era uma empresa fantástica, as oficinas da Estrada de Ferro tinham até uma história que eles sempre contavam com muito orgulho. Diziam que uma vez quebrou um avião aqui e iam mandar buscar uma peça fora e o Alberto Silva era diretor da estrada e ele disse: 'Não precisa, deixe que meu povo faz!!' e fizeram a peça para o avião [...] (grifos nossos).

Evangelina se recorda dos colegas de trabalho e do clima que, segundo ela, era amistoso entre os homens e as mulheres que foram encaminhadas para o escritório depois que a escola foi fechada. Segundo ela, a estrada mesmo já não mais existindo, pois tudo se resumia a um escritório onde ela trabalhava como Agente Administrativo de Pessoal. A entrevistada avalia que a Central do Piauí era uma "empresa fantástica" e lamenta sua desativação. Mais uma vez, essa declaração endossa o prestigio usufruído socialmente pelos ferroviários, que seriam, segundo ela, "tudo".

Para Evangelina, um dos destaques da empresa, além de oferecer serviço e um bom salário para os seus funcionários, era a oficina, aonde lá os ferroviários chegaram a fabricar até "peça para avião".

A professora aposentada Maria Helena, começou a trabalhar na década de 1950, como professora de Flores. Em 2013, aos 96 anos de idade, ainda guarda na memória as recordações de quando ingressou na escola:

Eu comecei a trabalhar na escola graças ao Alberto Silva. Nós éramos amigos e um dia ele perguntou: 'Maria Helena tu quer trabalhar na estrada?' Aí eu disse: 'eu acho que quero'. Eu era professora de flores e ganhava muito dinheiro. E eu ensinava a fazer flores. Mas entrei na verba quatro, quando a verba acabou eu sai. Ai ele voltou para estrada e eu voltei para estrada. Aí quando foi em 1976 começou um boato de que a estrada ia fechar e chegou um diretor, primo de uma amiga minha, e me mandou efetivar e eu fiquei efetiva. Em 1976, eu fiquei efetiva. Depois, aí teve um concurso e eu fiz o concurso e eu passei e fui ensinar letras. Quem pagava nosso salário era a Rede Ferroviária Federal. Nós éramos ferroviárias também. O salário era muito bom. Todo dia 05 eu recebia meu salário. Nunca atrasou. A escola funcionava de manhã e de tarde.

O relato da professora, assim como os anteriores, informa o caráter personalístico das nomeações e indicações e do estreito envolvimento entre os diretores da Estrada de Ferro no Piauí e as professoras, assim como já ocorria na nomeação dos ferroviários. 
Vicente de Paula Araújo Silva, filho do ferroviário Sebastião Lauro da Silva, conhecido como "Ição", que estudou na escola, guarda recordações da escola e do seu local de funcionamento da época em que foi aluno.

Estudei na Escola Técnica Familiar, que era uma escola que incialmente também funcionou na Sede do Ferroviário, era no prédio que foi casa do grande mestre fundador do colégio parnaibano, professor Lima Rebelo, tanto é que o colégio Estadual hoje tem o seu nome, Colégio Estadual Lima Rebelo. Então, eu estudei na escola técnica familiar que era escola dos ferroviários, cuja primeira série fiz lá, onde hoje funciona o Roland Jacob, onde era a casa do professor José Pires Lima Rebelo. Esse prédio ainda hoje existe é ali perto do anexo onde funciona a Secretaria de Educação do Município de Parnaíba, a Secretaria fica onde era a Sede da Diretoria da antiga Estrada de Ferro Central do Piauí e posteriormente RFFSA. Era uma escola de excelentes professores, o nível muito bom o dos professores, a minha professora era a dona Jesuíla Marinho, uma professora conhecidíssima, professora do Colégio das irmãs e professora lá. O nível dos professores era altíssimo, era o que poderia ter de melhor em Parnaíba, até porque os professores eram todos contratados pela estrada de ferro. Então o nível era muito bom, todo o pessoal que passou por lá estudou e foi além. Essa escola era também uma escola de doméstica, lá as mulheres aprendiam outras artes como bordar, costurar, fazer flores (grifos nossos).

A qualidade do ensino e o prestígio da escola são mais uma vez ressaltados pelo relato, assim como seu caráter de ensino prático para as demandas domésticas, como se fosse um caráter quase impositivo de se ser considerada uma "boa rainha do lar".

Realçar a qualidade do corpo docente da escola ferroviária ocorre de forma quase pleonástica nos relatos obtidos durante esta pesquisa. Este reconhecimento é responsável por muito do prestígio obtido pela escola. O ferroviário aposentado, Raimundo Nascimento, por exemplo, que começou a trabalhar na Central do Piauí na década de 1940, recorda-se da existência da escola e fala da importância para sua família, pelo ensino que receberam:

Meus filhos estudaram na escola dos ferroviários, o nome era Elzir Cabral, era ali do lado da Estrada de Ferro. Eu sou pai de nove filhos, cinco homens e quatro mulheres. Foi o Doutor Alberto Silva que fez esse colégio, não só leitura como também corte, costura e bordado para as filhas dos ferroviários aprenderem. Minha esposa não fez curso lá, mas minha filha, a Fátima, fez cursos, hoje ela mora no Rio de Janeiro. Foi ótimo! No dia da inauguração veio o Secretário de Educação do Brasil, cortou a fita simbólica no colégio. Foi muito animado!!!, as máquinas apitando, o pessoal soltando foguete, barril e mais barril de bebida.

O narrador lembra-se da festa que aconteceu na cidade no dia da inauguração do prédio, com a participação de autoridades cortando a fita. Segundo suas recordações, o dia foi marcado por uma grande festa.

Mais uma vez o nome de Alberto Silva ganha destaque no relato e, assim como nos demais, nenhuma pergunta mencionou o nome deste ex-diretor da Estrada de Ferro. Acreditamos que isso se deva à pujança da Estrada no período em que este engenheiro a administrou, assim como o período em que os entrevistados foram incorporados à companhia, o que inexoravelmente os relaciona ao 
seu ex-diretor, responsável pelas nomeações, algo, aliás, que marcaria sua trajetória também no cenário político piauiense posteriormente (FONTINELES, 2009).

\section{Considerações Finais}

Nesse trabalho tivemos como propósito investigar sobre a existência da escola para os filhos dos ferroviários piauienses localizada na cidade de Parnaíba e como essa escola marcou a memória daqueles que usufruíram de sua existência, seja como estudante ou professor. A pesquisa evidenciou o quanto a escola denotou o cenário educacional em vigência no país e no Estado, com a presença de valores muito caros às administrações varguistas, que sejam: sua marca cívica, moral e técnica, bem como deixou em evidência a presença do antigo diretor da Estrada de Ferro - Alberto Silva - na história da escola, seja na sua construção, quanto na contratação dos seus funcionários, inclusive profissionais que passaram a trabalhar na referida escola.

Ao longo das décadas de 1960 a 1980 a ferrovia piauiense passou por um longo processo de desmonte, que afetou também a escola, por esta estar sob a responsabilidade da ferrovia. A Central do Piauí, na década de 1960, depois da criação da Rede Ferroviária Federal, perdeu sua autonomia enquanto ferrovia e passou a ser um Distrito de Operações do Piauí - DOPI, subordinado à Rede de Viação Cearense. A escola passou a representar este novo domínio em sua denominação ao receber os nomes dos engenheiros cearenses: Escola Engenheiro Valdivino Leão de Carvalho do Núcleo Social Ferroviário Elzir Cabral.

No final da década de 1960, o DOPI passou a integrar a Estrada de Ferro São Luís-Teresina, com o nome de Distrito de Transportes do Piauí. Com essa mudança, a escola manteve o nome, mas foi com o nome de Elzir Cabral que ela ficou na memória dos parnaibanos que contribuíram com seus relatos orais para a presente pesquisa. É com saudades que os ferroviários, assim como as professoras e alunos, se recordam da escola. São envolvidos por sentimentos e ressentimentos em relação à desativação da Central do Piauí e consequentemente da escola e isso fica evidenciado em seus relatos.

\section{Referências}

ALBERTI, Verena. Ouvir contar. Textos em história oral. Rio de Janeiro: FGV, 2014.

ALMANAQUE da Parnaíba, Parnaíba, 1944.

ALMANAQUE do Cariri, Teresina, 1952.

ASSMANN, Aleida. Espaços da recordação: formas e transformações da memória cultural. Tradução: Paulo Soeth. Campinas, SP: Ed. UNICAMP, 2011. 
BENJAMIN, Walter. Magia e técnica, arte e política: ensaios sobre literatura e história da cultura. (Obras Escolhidas, vol. I). São Paulo: Brasiliense, 1994.

CASTELO BRANCO, Renato. Tomei um Ita no Norte (memórias). São Paulo: L.R. Ed., 1981.

CERTEAU, Michel de. A invenção do cotidiano: 1 - artes de fazer. Petrópolis, RJ: Vozes, 2003.

ESTRADA de Ferro - Festa Cívica. A Semana, Parnahyba, anno I, n. 2, p. 01, 26 de nov. de 1916.

FONTINELES, Cláudia Cristina da Silva. O Recinto do Elogio e da Crítica: maneiras de durar de Alberto Silva na memória e na história do Piauí. 2009. 374 f. Tese (Doutorado em História) -

Universidade Federal de Pernambuco, Recife, 2009.

GINZBURG, Carlos. Mitos, emblemas, sinais: morfologia e história. São Paulo: Companhia das letras, 1989.

HARDMAN, Francisco Foot. Trem-Fantasma: a ferrovia Madeira-Mamoré e a modernidade na selva. 2. ed. São Paulo: Companhia das letras, 2005.

LIMA, Maria Helena Brandão. Entrevista concedida a Maria Dalva Fontenele Cerqueira, Parnaíba 17 de novembro de 2013.

NASCIMENTO, Raimundo Ribeiro. Entrevista concedida a Maria Dalva Fontenele Cerqueira. Parnaíba, 06 de abril de 2014.

NORA, Pierre. Le lieux de mémorie, v. 2. Paris: Quarto Gallimnard, 1997.

PELA E. F. Central do Piauí. O Piauí, Teresina, ano 62, n. 753, p. 02, 24 de jan. 1952.

POLLAK, Michael. Memória e identidade social. Estudos Históricos, Rio de Janeiro, v. 5, n. 10, p. 200-212, 1992.

REBELO, Goethe Pires de Lima. Tempos que não voltam mais: crônicas sobre a Parnaíba antiga. Rio de Janeiro: ADOIS, [s.d].

REZENDE, Antonio Paulo. A complexa cartografia instável dos sentimentos. Disponível em A astúcia de Ulisses, em 26/07/2012. Consultado em 05/10/2015.

BRILHANTE discurso do Jornalista Batista Leão, Chefe de Relações Públicas do EFCP. Revista Contemporânea, Fortaleza, ano XXI, n. 103, p. 28-29, set./out. 1960.

RIBEIRO, Maria Luísa Santos. História da Educação Brasileira: a organização escolar, 20. ed. Campinas, SP: Autores Associados, 2007.

SILVA, Vicente de Paula Araújo. Entrevista concedida a Maria Dalva Fontenele Cerqueira, Parnaíba 09 de abril de 2014.

SOUZA, Evangelina Maria Silva e. Entrevista concedida a pesquisadora Maria Dalva Fontenele Cerqueira, Parnaíba 10 de novembro de 2014. 